\title{
Литература
}

Бегунов Ю. К. Памятник русской литературы XIII века «Слово о погибели Русской земли». М.; ․, 1965.

Бегунов Ю. К. Князь Александр Невский и его эпоха. Исследования и материалы. СПб., 1995.

Горский $A . A$. Свидетели путешествия Плано Карпини: уникальная информаџия и ошибки прочтения / / Древняя Русь. Вопросы медиевистики. 2014. № 3 (57). С. 115-121. [Горский, 2014а]

Горский A. A. Об обстоятельствах гибели великого князя Ярослава Всеволодича // «По любви, въправд8, безо всАкие хитрости». Друзья и коллеги к 80-летию Владимира Андреевича Кучкина. Сборник статей. М., 2014. С. 179-190. [Горский, 20146]

Григорьев А. П. Конкретные формуляры чингизидских жалованных грамот XIII-XV вв. // Тюркологический сборник. 1974. M., 1978. C. 198-218.

Егоров В. А. Александр Невский и Чингизиды // Отечественная история. 1997. № 2. С. 48-58.

Кучкин B. A. Монголо-татарское иго в освешении древнерусских книжников (XIII - первая четверть XIV века) // Русская культура в условиях иноземного нашествия и войн. X - начало XX века. М., 1990. Вып. 1. C. 15-69.

Лурье Я. С. К изучению летописной традиџии об Александре Невском // ТОДРЛ. СПб., 1996. Т. 50. C. 387-399.

Лурье Я. С. Ордынское иго и Александр Невский: источники и историография ХХ в. // Лурье Я. С. Россия древняя и Россия новая. СПб., 1997. С. 100-130.

Svetlana A. Maslova

Institute of Russian History of the Russian Academy of Sciences, Moscow, Russia

\section{THE EMBASSY OF THE “ORIENT TSAR” TO ALEXANDER NEVSKY}

The initiator of the embassy to Aleksandr Nevsky is appointed in the article. The comparison of the different primary sources has demonstrated the maximum likelihood of the embassy from the capital of the Mongol Empire.

Keywords: Aleksandr Nevsky, envoys, Batu, Guuk, Turakina

УДК 913.1, 913.8, 930.25, 930.85, 93/94 ББК 63.3(2)4, 63.2 DOI 10.25986/IRI.2019.75.1.0019

T. A. Матасова

МГУ им. М. В. Ломоносова, Москва, Россия. tamatt2009@gmail.com

\section{ДВА СПИСКА ДРЕВНЕРУССКОГО ПЕРЕВОДА ПЕРВОЙ КНИГИ «ГЕОГРАСИИ» ПОМПОНИЯ МЕЛЫ ВРЕМЕН МИХАИЛА РОМАНОВА}

В статье представлены итоги изучения двух кодексов первой половины XVII в., содержащих древнерусский перевод Первой книги «Географии» Помпония Мелы. Сделанные наблюдения подкрепляют и углубляют выводы, к которым автор пришел ранее, исследуя другие русские средневековые списки этого трактата.

Ключевые слова: «Георафия» Помпония Мелы, древнерусский перевод, провиденииализм, восприятис

В 2016 г. увидела свет публикаџия древнерусского перевода Первой книги «Географии» Помпония Мелы, в которой были учтены пять обнаруженных к тому времени списков этого текста XV-XVII в. [Матасова]. В недавнее время К. В. Вершинин обратил наше внимание еше на два списка перевода трактата (один - из коллекции Отдела рукописей ГИМ ${ }^{1}$, другой - из собрания Государственного архива Ярославской области $\left.{ }^{2}\right)$, которые не были учтены при подготовке издания. Џель данной статьи - анализ этих списков, в том числе рассмотрение вопроса о восприятии текста Мелы русскими книжниками в 30-40-е годы XVII столетия.

Рукопись из собрания А. С. Уварова Отдела рукописей ГИМ (далее - У) представляет собой Хронограф редакџии 1617 г., к которому добавлены изучаемы текст, а также перевод «Космографии» Абрахама Ортелиуса и еше некоторые богословские и географические сочинения. Рукопись восходит к 1630 -м годам, о чем свидетельствуют как водяные знаки ${ }^{3}$, так и содержание рукописи: последнее известие Хронографа датировано 1630 г. ( $\curlywedge$. 513 об.). О рукописи известно, что в конџе XVII в. она находилась в одном из монастырей Владимира ${ }^{4}$. Текст «Географии» Помпония Мелы написан тем же почерком, что и Хронограф, а также большинство других текстов кодекса.

1 ГИМ. Собр. А. С. Уварова. № 7 (1º). ㅅ. 584-597 об. См. описание: [Леонид (Кавелин), с. 56-60, № 1368 (8)].

2 ГАЯО. Колл. рукописей. № 457 (43). ‥ 265-286 об. См. описание: [Лукьянов, с. 87-88].

3 На большинстве листов сборника, в том числе на л. 584, 585, филигрань «кувшин» - сходство с Heawood № 3583 (1621 г.). «Кувшины» близких типов на л. 586, 588, 590, 592, 595, 596 пока точно не идентифиџированы. Все они представляют собой кувшины с двумя выведенными одной чертой ручками с завитками; на крышке шесть виноградин (на трех лежат две, на двух - одна), которые венчает «цветочек» из трех лепестков $(\lambda .586,588,595)$ или крестик $(\lambda .590,592,596)$; крестик этот выглядит как на кувшинах типа Дианова (кувшин) № 377 (1622 г.) и № 378 (1621 г.). На горле нет ничего (кроме л. 588, где видны две линии). На туловах кувшинов нет букв, на л. 586 - завитки, на остальных - три кружочка (один лежит на двух). Стоян на всех кувшинах не отделен линией от поддона, имеюшего уступы. В шелом, все эти филиграни относятся к тому же типу, что Гераклитов № 776, 780 (1625 г.); Дианова, Костюхина № 759 (1624 г.), № 760 (1629 г.); Дианова (кувшин) № 364 $(1625,1630,1631$ г. $)$.

${ }^{4}$ Об этом повествует владельческая надпись [Леонид (Кавелин), с. 57]. 
Рукопись из ГАЯО (далее - Я) представляет собой сборник смешанного содержания 5 . Значительную часть сборника составляют произведения Мефодия Патарского («о Бозе, о веши и о самовластьстве» ( $($. 16-46), «о житии и деянии разумне» (Л. 46-55 об.), три слова «о Воскресении» (первое - л. 55 об.-126, второе л. 126 об.-173, третье - л. 173-205 об.), «о разлучении яди и о юниџе менимеи» ( Л. 205 об.-229), «о прокажении» (Л. 229-248 об.) и «о пиявиџе» (Л. 248 об.-262 об.)). Примечательно, что здесь собрано более половины всех известных в славянской и русской письменности произведений этого выдаюшегося экзегета (ср.: [Даниленко, с. 370]). После этих текстов оставлено два пустых листа, сразу за которыми следует «География Помпония Мелы»

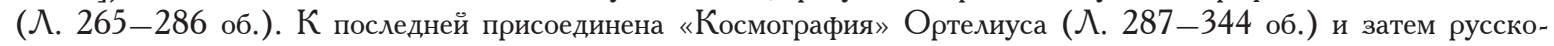
греческий словарь ярко выраженного христианского содержания («Язык греческий», включаюший, впрочем, перевод не только греческих, но и отдельных слов с «еврейского», «египетского», «еллинского», «римского» и славянских языков $($ ․ 345-385 об. $))^{6}$. Этот словарь состоит из многих тематических разделов, из них последние четыре были ошибочно приняты в описании за отдельные произведения [Лукьянов, с. 88] ${ }^{7}$. Затем следует выдержка из рассказа о принятии христианской веры князем Владимиром (Л. 386-388), впервые читаюшегося в Повести временных лет и повторенного в џелом ряде более поздних летописных сводов (фрагмент рассказа греческого философа, где он излагает ветхозаветные пророчества о Христе $\left.{ }^{8}\right)$. Завершают сборник написанные более поздним почерком

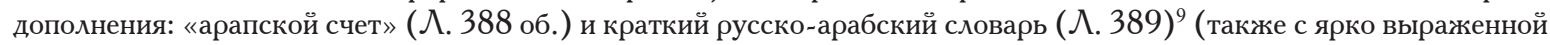
христианской направленностью). Сборник может быть датирован первой половиной 40 -х годов XVII столетия ${ }^{10}$. Составляюшие сборник тексты написаны разными, но очень похожими почерками середины XVII в. Сохранившийся с XVII в. «родной» переплет сборника означает, что все тексты, даже если изначально и не составляли единого кодекса, к середине XVII в. были объединены под одной обложкой. Сборник, вероятно, происходит из коллекџии Ярославской духовной семинарии ${ }^{11}$ [Лукьянов, с. 3]. Владельческие записи обнаруживают, что ранее рукопись принадлежала частным лиџам и, по-видимому, переходила из рук в руки ${ }^{12}$.

Любопытно, что в обеих рукописях текст «Географии» Помпония Мелы соседствует с переведенной в Москве во второй четверти XVII в. [Казакова, с. 130] «Космографией» Ортелиуса, что может говорить о восприятии текста Мелы даже в XVII в. как собрания актуальных сведений об окружающем мире. Действительность в ту пору, впрочем, воспринималась провиденџиально, и потому эти географические трактаты находятся в сборниках в окружении текстов, пронизанных традиџионными идеями.

Особенно ярко это отразилось в Я, где произведение Мелы предваряется словами Мефодия Патарского, в которых присутствует немало фрагментов, в смысловом и образном отношениях близких тексту Мелы. Римский географ повествует о земных и водных пространствах, об их флоре и фауне, о народах и примечательных местах. Тексты Мефодия также полны разнообразных природных аллюзий. Так, в слове «о пиявиџе» автор не раз использует для иллюстраџии своих идей образы моря, рек, птиџ, насекомых и т. д.

Многочисленные смысловые параллели очевидны. В начале слова «о пиявиџе» присутствует яркий образ пчелы, «обретаюшей медвеные источники» (Я. ‥ 249; ср.: [Даниленко, с. 376]), а в древнерусском переводе Мелы тоже есть загадочная пчела, которую египтяне «чтут аки божествену» [Матасова, с. 338]. В том же слове Мефодий рассказывает о «пиявиџе», которая будто выпрыгивает из рек и, впиваясь в человека, начинает сосать из него кровь (Я. А. 251 об.; ср.: [Даниленко, с. 378]). Похожий сюжет есть и у Мелы, который повествует о выпрыгиваюших из реки змеях, которые ловят и съедают летяџих над водой птиџ [Матасова, с. 344]. У Мефодия - с опорой на 73-й псалом - упомянуты эфиопы и «Әфиопская страна» (Я. ᄉ․ 253; ср.: [Даниленко, с. 379]), а у Мелы тоже подробно рассказано об Эфиопии [Матасова, с. 331, 336 и др.]. Список примеров можно продолжить.

Особое внимание стоит обратить на то, что у Мефодия проџитирован 103-й псалом, где речь идет о «великом и пространном море», наполненном различными чудесными животными (Пс 103: 25-26) (Я. ᄉ. 252; ср.:

В отличие от обстоятельного описания $У$, составленного архимандритом Леонидом, описание Я, осуществленное В. В. Лукьяновым, характеризуется многочисленными неточностями и даже ошибками, что, впрочем, не стоит ставить в вину автору, каталог которого в целом имеет большое значение.

6 Автор предполагает в ближайшее время заняться изучением этого текста.

7 ‥ 374 об.-379 об. - «Невъдомыя ръчи, наже өбрђтаются во стых книгах ют греческагю и ют еврейска назыка»; л. 379 об. -382 об. - «Толкованіе не8добь познаваемымъ в писаніих ръчем...»; л. 383-384 об. - «Имена зеліем, на составленіе мира»; л. 384 об. -385 об. - «Произвюлники ๒ Ц

${ }^{8}$ Повесть временных лет. М.; ᄉ., 1950. Т. 1. С. 68-71.

${ }^{9}$ См.: [Морозов]. Говоря о составе сборника (с. 248), Д. А. Морозов опирался на описание В. В. Лукьянова и потому повторил неточности, которое оно содержит.

10 Филиграни: 1. Лилия в шите с короной - близко: Дианова, Костюхина № 918 (1640 г.); 2. Голова шута в трех вариантах: а) подобие: Гераклитов № 1177 (1642г.); б) сходство (без букв): Дианова (голова шута) № 52 (1653 г.); в) соответствие пока не найдено; 3. столбы с виноградом - сходство: Дианова (Украина и Литва) № 740 (1644 г.); 4-5. Кувшин в двух вариантах, соответствие пока не найдено. Обе филиграни представляют «кувшин» сходной формы: с одной ручкой с двойным очерком, на крышке гребешок, в первом варианте гребешок из четырех зубчиков, во втором - из пяти; над гребешком полумесяџ. В первом варианте кувшина второй зубчик, во втором варианте - третий зубчик немного выше остальных; на тулове кувшинов буквы в пояске: в первом варианте - ВР, во втором - ВВ. Основываясь на материалах составленного Т. В. Диановой альбома филиграней (Дианова (кувшин) № 77-105), можно заметить, что подобные типы гребешков без украшений на зубчиках на кувшинах с одной ручкой и буквами на тулове в пояске были характерны для бумаги конџа 1630 -х - начала 1640 -х годов.

${ }_{11}$ На последнем припереплетном листе запись, сделанная, вероятно, библиотекарем семинарии: «№ 34.15-29-41. Меөодія филиппиіскаго, Козмографіи и Греческий языкъ».

${ }_{12}$ На л. 1 владельческая запись 1832 г. («Сія книга Дъониса Леоньтьева Лвова 1832 го(д)»; автор благодарит А. Е. Тарасова за помошь в расшифровке записи), а также на л. 389 об. почерком XIX в. написано имя «Иванъ Михайловъ Стукачевъ». 
[Даниленко, с. 378]). Это примечательно, поскольку в самом раннем полном списке перевода Мелы из собрания РГАДА именно эти слова џаря Давида, скорее всего, вспомнились книжнику, когда он - вероятно, одним из первых на Руси! - читал о природе Египта в изложении римского географа [Матасова, с. 314, 336-339]. Впрочем, в Я подобных (и каких-либо других) маргиналий нет.

Русские книжники соотносили в своем сознании образы, встречаюшиеся у Мефодия и у Мелы,

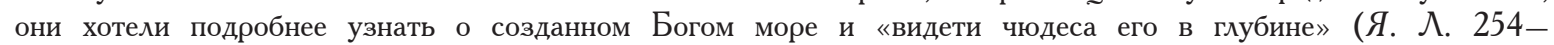
254 об.; ср.: [Даниленко, с. 380]), будь то жаждущая человеческой крови «пиявиџа, сожительниџа змиева» (Я. ․ 255 об.; ср.: [Даниленко, с. 381]) или то, как «пречюдная чюдеса Христова сотворят делеса въ водах многахъ» (Я. А. 255; ср.: [Даниленко, с. 381] $\left.{ }^{13}\right)$. Книжники стремились постичь свидетельства любви Божьей «ко всем языкам», Который «поистине оубо оуловиша ны от кумироверия» (Я. А. 255; ср.: [Даниленко, с. 381]), но также и узнать о кумирах, «мольбиџа» и «позориџа» (изображения, статуи) [Матасова, с. 300] которых стоят, согласно Меле, в разных частях ойкумены.

Таким образом, текст Мелы из Я, соседствующий со словом «о пиявиџе», играет роль своеобразного пространного комментария к нему (и к другим помешенным в сборнике текстам Мефодия, также исполненным библейских образов природы). Не в меньшей степени текст Мелы выполняет - наряду с «Космографией» Ортелиуса и функџию сообщения сведений о мирских «диковинах» и организаџии окружающего пространства.

Сходная картина заметна и применительно к У, где известия Мелы дополняют сведения о чудесных реках, морях, народах, животных и растениях, содержашихся в начальных частях Хронографа 1617 г., изложение которого также основано на убеждении, что «Богъ есть надо всеми веки и преже бытия всея твари, преже света разумнаго, присно в Себе сый...» (У. ᄉ. 19).

Большое значение в данном контексте имеет приведенный в Я, но никак не озаглавленный фрагмент из рассказа греческого философа князю Владимиру о ветхозаветных пророчествах о Христе. Этот фрагмент, по-видимому, был включен в сборник не случайно. Здесь присутствует законченная смысловая линия: Господь обратился «ко всем языкам» и просветил их, когда ветхозаветные иудеи отошли от Бога. В тексте подчеркивается, что «все языки» даже более любимы Богом, чем отошедшие от Него иудеи. Гневаясь на иудеев, Господь возгласил: «Отрину от себе и призову иныя люди, иже мене послушают. Аше и согрешят, не помяну беззакония их» (Я. ㅅ. 386). Согласно пророчеству Малахии, Господь будет присутствовать в жизни всех народов и всех культур: «От востока и до запада имя Мое прославися во языџех, и на всяком месте приносятся кадило имени Моему и жертва честна, зане же велие имя Мое во языџех» (Я. ․ 386 об.). Рассказ о «всех языках» прямо связан с осмыслением географического пространства как такового, он задает тон пониманию конкретных сведений из Мелы и Ортелиуса. Присутствие этого отрывка в сборнике позволяет предположить, что его составителю была близка мысль о неизбежной христианизаџии всех людей, даже тех, которые, как сказано у Мелы, «молятся солнџу», чтут «позорише бога Аполлона», «мольбишо Зевсово», «боле зычат, нежели говорят», «мало спят» [Матасова, с. 335, 337, 342, 343, 345] и т. д. Для интеллектуальной жизни России середины XVII в. идея «всемирного торжества православия» была одной из ключевых. В рассматриваемом случае она проявилась с необычайной полнотой и силой.

Приведенные примеры демонстрируют, что известия Мелы (и «Космографии» Ортелиуса) даже в 1640-е годы воспринимались почти так же, как и в более ранее время, - через призму провиденциальных идей.

Особенность $У$ в том, что в нем присутствуют маргиналии, связанные с обозначением содержания отдельных разделов текста. Эти пометы сделаны киноварью и - в отличие от маргиналий из списка РГАДА [Матасова, с. 293, 314] - носят систематический характер. Они призваны облегчить поиск в тексте и обозначают его отдельные сюжеты, выполняя функџию подзаголовков, не содержаших каких бы то ни было размышлений и ассоџиаџий. В той же манере выполнены и пометы, обрамляюшие Хронограф 1617 г.

Примечательны пометы рядом с описанием Нила и его разливов: «(Ниль реки и юстровех речных», «ю родъх речных скотъхъ», «ю дыханіи водном», «ю нахоженіи скот речных несовершеных» (У. ․ 590 об.-591) и т. п. В них нет и намека на осознание близости известий Мелы с псалмами или другими библейскими текстами (что было так важно для книжников конуа XV - первой половины XVI в. [Матасова, с. 314-317] и даже для составителя Я). Был ли для переписчика У провиденџиальный контекст менее значим, чем для книжников, работавших над Я?.. Если так, У можно считать своего рода «переходным» звеном от сугубо традиџионного восприятия известий Мелы к более светскому, хотя эту тенденџию не стоит преувеличивать, учитывая конвой памятника.

Сплошное сличение текстов исследуемых списков с публикаџией дало предсказуемые результаты. Оба списка полные, без существенных утрат и дополнительных приписок, что подтверждает тезис о единственной редакџии

\footnotetext{
13 В списке Мефодия, по которому подготовлена публикаџия, вместо «делеса» - «телеса».
} 


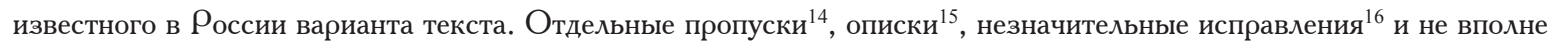
схожее написание слов в силу вариативности орфографии обычны для проџесса копирования. Многие особенности передачи имен собственных, присутствуюшие в $V_{\text {и }} Я$, есть и в уже исследованных списках (так, египетского бога Амона переписчики $Я$ и $У$ именуют Аммоном ${ }^{17}$; вероятно, так было и в протографах этих списков). Оба списка близки Егоровскому и Большаковскому спискам [Матасова, с. 289-294], но особенно - списку 1680-х годов, содержашемуся в составе сборника географического содержания, который происходит из библиотеки Чудова монастыря ${ }^{18}$. Однако едва ли один из изучаемых списков был протографом Чудовского ${ }^{19}$. Нельзя исключать, что каждый список имел свой протограф.

Итак, проведенное исследование двух не учтенных при публикаџии списков древнерусского перевода «Географии» Помпония Мелы подтверждает и расширяет сделанные ранее выводы о преимушественно провиденџиальном восприятии русскими книжниками известий римского автора, по крайней мере, до последней четверти XVII в. [Матасова, с. 323]. Рассмотренные кодексы содержат во многом уникальный материал, дающий широкие возможности для дальнейших размышлений о путях рефлексии русских книжников первой половины XVII столетия о географическом пространстве.

\section{Литература}

Даниленко Б., прот. Славянские переводы творений святого Мефодия Патарского. К вопросу о славянской версии ранних святоотеческих текстов, посвященных библейской экзегезе // Studi Slavistici. 2016. Vol. XIII. P. 369-388.

Казакова Н. А. Русский перевод XVII в. “Theatrum Orbis Terrarum” А. Ортелия // ВИД. А., 1987. Вып. XVIII. С. 121131.

Леонид (Кавелин), архим. Систематическое описание славяно-русских рукописей собрания графа А. С. Уварова. М., 1894. Ч. 3.

Лукьянов В. В. Описание коллекџии рукописей Государственного архива Ярославской области XIV-XX вв. Ярославль, 1957.

Mатасова T. A. Античный географический трактат в Московской Руси: Первая книга «Географии» Помпония Мелы в древнерусском переводе // Средневековая Русь. М., 2016. Вып. 12. С. 283-348.

Морозов Д. А. Русско-арабский глоссарий XVII в. времен Павла Алеппского // Россия и Христианский Восток. М., 2015. Вып. 4-5. С. 247-255.

Новикова О. А. Фрагмент Первой книги «Географии» Помпония Мелы в Соловеџкой рукописи конџа XV века // Вестник Альянс-Архео. 2015. № 10. С. 35-75.

14 В У пропушены слова «ему же вселенную и небо имя дахом едино есть» (Л. 584 об., ср.: [Матасова, с. 326]), «или паки с собою прибывает» (Л. 591; ср.: [Матасова, с. 336]), «Дестрос пловом от кораблеи а Карафос» ( . 593 об.; ср.: [Матасова, с. 341]). В Я пропушены «и от верховия» (Л. 267 об.; ср.: [Матасова, с. 328]), «того иного Валинонии близ же» ( $(268$ об., ср.: [Матасова, с. 329]), «Утика и Карфаген оба славныа грады» (Л. 273, ср.: [Матасова, с. 333]), «и брань велия створится» (Л. 274, ср.: [Матасова, с. 334]). В У и Я есть и другие незначительные пропуски длиной от одного до - редко - шести-семи слов.

15 Например, в У вместо «савромати» - «самоврати» ( $\curlywedge$. 597), вместо «Понтскому»/ «Понтискому» - «Понскому» ( $\mathcal{} .586$ об.); в Я вместо «Пафлагонскии» - «Павлагоньски» (Л. 285), вместо «Нурани. Вергети» [Матасова, с. 329] - «Нураниве. Ргети» (Л. 268 об.). И мн. др.

${ }^{16}$ Например, в Я передача чисел не словом, а џифирью (Л. 277, 278-278 об.), ср.: [Матасова, с. 337-338].

17 У. ᄉ. 589 об.; Я. ᄉ. 274. Ср.: [Матасова, с. 334].

${ }_{18}$ В обоих списках присутствуют чтения имен собственных, характерные именно для Чудовского списка. Например, вместо «и стваряет [Нил] от земли живушая» [Матасова, с. 336, примеч. 414] - «испаряет» (У. ․ 591; Я. ‥ 276) и др. Примечательна и тождественная передача отдельных фраз (вместо слов «преже бело поле» - в Чудовском списке [Матасова, с. 337, примеч. 451], а также в У и Я читается «в оно было поле» (У. ․ 591 об.; Я. ‥ 277); о важности этой фразы см.: [Новикова, с. 42]) и Фрагментов текста (вместо слов «у тех Раматъ, поведають, жонкамъ моужскаа дела делати, а мужикомъ женьская дела делати, жонкам коньноую брань створяють, мужи же пешую брань стваряють» - в Чудовском списке [Матасова, с. 347, примеч. 897-900], а также в $У$ и Я слова «У тех рамат, поведают, жонкам мужская дела, мужиком же женская дела делати сотворяют. Моужи ж пешую брань сотворяють, жены ж конную брань» (У. А. 597; Я. А. 286). И др.

19 Например, в У и Я присутствует верное чтение «есть в Палестине Гадза» (У. ․ 592 об.; Я. ‥ 279), а в Чудовском списке - с ошибкой: «есть в Палестине сад за...» [Матасова, с. 339, примеч. 556]. Встречаются и другие разночтения: вместо «гора Аманос» [Матасова, с. 340] - «гора Амонос» (У. ‥ 593; Я. А. 280) и т. д. В каждом из исследуемых списков есть и оригинальные чтения. В $У$ «Милиптос» (Л. 594 об.) вместо «Милепос» [Матасова, с. 343], «Гречанину» (Л. 595 об.) и

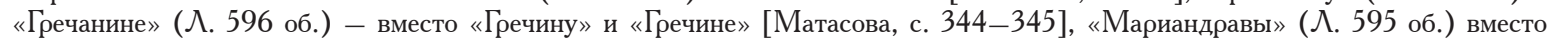
«Мариандавы» [Матасова, с. 344] и др. В Я вместо «Касписа моря» [Матасова, с. 328] - «Кастаи моря» (Л. 268), вместо «Камъвискъ» [Матасова, с. 339] - «Камбис» (Л. 279), вместо «Тауровым»/«Тоуровым» [Матасова, с. 341, примеч. 640] «Испауровым» (Л. 281), вместо «явления» [Матасова, с. 344] - «видения» (Л. 284) и др. 
The article presents the main results of the complex analysis of two codexes dating back to the $17^{\text {th }}$ century which contain the Old Russian translation of "Cosmography" by Pomponius Mela. The main conclusions confirm and deepen the observations made before and based on the other copies of the text.

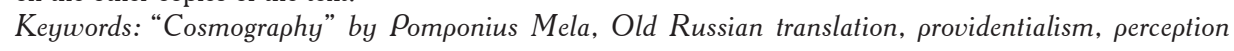

УДК 947.02/.04:327(094.2) ББК 63.2 DOI 10.25986/IRI.2019.75.1.0020

Е. А. Мельникова

ИВИ РАН, Москва, Россия. melnikova_2002@mail.ru

НЕСКОЛЬКО ЗАМЕЧАНИЙ О ЯЗЫКЕ «СКАЗАНИЯ О ПРИЗВАНИИ ВАРЯГОВ ${ }^{1}$

В статье рассматривается отличительная особенность языка «Сказания о призвании варяжских князей» - использование парных синонимических словосочетаний (субстантивных, вербальных, атрибутивных), которые типичны для фольклорного текста, но отсутствуют в других частях летописей. Тот же тип словосочетаний представлен в преамбуле и эсхатоколе русско-византийского договора 911 г. Эта особенность может свидетельствовать об отражении своего рода «юридического языка» в «ряде» с варягами (ядре «Сказания») и близком по времени договоре 911 г.

Ключевые слова: «Сказание о призвании варяжских князей», парные синонимические словосочетания, руссковизантийский договор 911 г.

Язык «Сказания о первых русских князьях» [Шахматов, с. 210-244], или «Древнейшего сказания», или «Ядра» [Гимон], считается относительно гомогенным ${ }^{2}$ «Речь летописџев ясна и проста... Речь эта энергична, глагольна, сказуемое обычно выдвинуто на первое место... События, действия, движение - вот что стремятся передать летописџы, и эта задача требовала слога ясного, не осложненного украшениями» [Шайкин, с. 326]. Это определение относится ко всему летописному тексту, но оно особенно актуально для характеристики языка «Древнейшего сказания», которое представляет собой лапидарный пересказ бытовавших во время его составления исторических преданий, отобранных и выстроенных в последовательный нарратив - череду правлений первых русских князей³. Язык этих пересказов сух и лишен красочности: сообшаются лишь основные перипетии сюжета (его «скелет»), в результате чего безусловно доминируют субстантивные и глагольные лексемы ${ }^{4}$. Текст «Древнейшего сказания» содержит устойчивые словосочетания, характерные и для последуюшего повествования, как, например, «совкупи вои многы» (под 944 г.), «сеча зла» (под 971 г. и др.) [Творогов], но в незначительном количестве и преимущественно в рассказах о военных действиях, особенно походах Святослава [Орлов].

На этом фоне выделяется «Сказание о призвании варягов», насыщенное парными синонимичными словосочетаниями, которые в большинстве своем не повторяются в последуюшем тексте летописи, но по своим морфологическим и семантическим характеристикам близки фольклорным двухкомпонентным структурам устойчивым сочетаниям слов, принадлежаших к одному лексико-грамматическому разряду 5 . В общей сложности таких словосочетаний в «Сказании» шесть (или семь) ${ }^{6}$ :

\footnotetext{
${ }^{1}$ Статья написана в рамках работы над проектом № 18-09-00433\18, поддержанным ОГОН-РФрсрИ. Сердечно благодарю Т. В. Гимона за џенные замечания и соображения, которые помогли мне в работе над статьей.

2 Б. А. Успенский определяет его как џерковнославянский, хотя он «нередко предстает как русифиџированный (в той или иной степени)» [Успенский, с. 101]. См. также: [Гимон, с. 768-769].

3 Реконструкшии древнейшего текста, легшего в основу летописания см.: [Шахматов, с. 385-456; Михеев, c. $210-254]$.

${ }_{4}$ О художественной роли глаголов в языке летописных текстов см.: [Шайкин, с. 327-329].

5 См. подробно: [Хроленко]. Автор использует вошедший затем в лингвофольклористику термин «репрезентативные пары», под которыми понимаются устойчивые словосочетания.

6 Из приводимого ниже текста исключены общепризнанные вставки летописџев конџа XI - начала XII в. Полужирным шрифтом выделены парные синонимические словосочетания.
} 